\title{
Communication in the Language of Flowers
}

Kenneth O. D oyle' ${ }^{1}$, Anne M. H anchek², and J ulia M cG rew ${ }^{3}$

Additional index words. marketing, cut flowers, color psychology, people-plant interaction

Summary. Flowers communicate information and emotion. When people were asked what messages they associated with given floral arrangements, they reliably connected six meanings with particular arrangements. When similar people were asked which floral arrangements they would choose to convey given messages, they reliably associated three arrangements with particular messages. These findings are consistent with previous studies of the psychology of personality and color; with further elaboration, they should be useful in floral advertising and marketing, advertising, and marketing in other fields, and communications research.

any of us use flowers to send messages to other people"congratulations" to a promoted business associate, "thank you" to a valued teacher, "I apologize" to a hurt or angry spouse. Accompanying notes or greeting cards often contain these very words and sentiments. Flowers also may convey specific meanings. From ancient E gypt to medieval Europe, flowers were used as symbols for abstract concepts such as power, love, and remembrance. In V ictorian times, a more-precise florigraphy, commonly called the language of flowers, involving a complex and extensive grammar and syntax was introduced from the harems of Turkey and Egypt (M arsh and G reenaway, 1978). Lovers, for example, were advised by one authority to present white roses to the objects of their desire to indicate "I am worthy of you," and a 'La France' rose to set a date to "meet me by moonlight" (Anonymous, 1968). There were several problems with this flowery language, however. First, it was inconsistent, perhaps even arbitrary. A marigold, in general, communicated grief and despair, while a French marigold suggested jealousy. As Pickles (1990) said, "It is curious that the [white lilac] should symbolize such pure sentiments [as Youthful I nnocence] for in some villages a lilac branch is said to signify a broken engagement." Second, the language was too complex for general application.

\footnotetext{
${ }^{1} \mathrm{R}$ esearch A ssociate. School of J ournalism and M ass C ommunication, U niversity of M innesota, M inneapolis, M N 55455

${ }^{2} \mathrm{~A}$ ssistant Professor. D epartment of $\mathrm{H}$ orticultural Science, U niversity of M innesota, St. Paul, M N 55108.

${ }^{3}$ Graduate A ssistant and Wright C ounty Extensi on Educator. D epartment of H orticultural Science, U niversity of M innesota, St. Paul, MN 55108.

Minnesota A gricultural Experiment Station publication no. 20997, partiallyfunded bytheM innesota LandscapeA rbor etum. Wethank theM innesota Extensi on Service4-H Program for theuse of their statefair facilities. Thecost of publishing thispaper wasdefrayed in part bythe payment of pagecharges U nder postal regulations, thispaper ther eforemust beher eby marked advertisement solely to indicatethis fact.
} 


"In contem-
porary A merica,
thereare still
signsthat
different kinds of
flowers convey
particular
meanings"

In 19th-century England, nearly 150 florigraphy dictionaries were published ( $M$ arsh and Greenaway, 1978), and the semianonymous "F.W.L." writing in 1913 listed more than 700 specific messages tied to many plants, plant parts, and flower colors (Anonymous, 1968). Finally, the historical language of flowers required many flowers that are no longer readily available in the marketplace, such as camellia, mustard, and valerian.

In contemporary A merica, there are still signs that different kinds of flowers convey particular meanings. "I love you" roses are available at many convenience stores and "in memoriam" lilies are available at floral shops. Furthermore, it would be a brave employee who would welcome a new male boss with a pink pansy. The notion of a specific language of flowers continues to intrigue people and provides good material for popular magazine and newspaper articles (Anonymous, 1991; Keenan, 1990). But such information may have more serioususes as well. I t may be vital in floral advertising and marketing (Professional Plant G rowersAssn., 1991), and it may beindirectly useful in advertising and marketing campaigns in other fields such as interior design and automobile design. And, because it focuses on symbolic communication between people, it may also be useful in general communications research.

The purpose of our ongoing project is to test whether a modern language of flowers exists and, if so, to determine the vo cabulary, grammar, and syntax of that language. Reported here are the results of two pilot studies beginning explorations into what may be an enormously complex people-plant interaction.

\section{M aterials and methods}

This report comprises two simultaneous but distinct studies. The first study was designed to elicit connotative meanings associated with different flowers; it relied on the semantic differential technique widely used in the social sciences for such purposes, in which subjects rate objects on scales anchored by pairs of contrasting adjectives or nouns, like beautiful and ugly (O sgoode, 1952). The second study was designed to connect particular flowerswith particular messages, such as "I loveyou." I t used aquestionnaire that asked subjects which arrangement in a given display they would most prefer to send the message to someone. We separated the two studies because doing both tasks would likely have been burdensome to the subjects and would probably have discouraged participation.

The subjects were a sample of people who attended the $1990 \mathrm{M}$ innesotaStateFair.
Volunteer participants were enlisted by signs and public address announcements as they entered the 4- $\mathrm{H}$ building, enticed by a gift packet of seeds and hourly drawings for a variety of attractiveindoor and outdoor plants. Of the total group of 313 subjects, $77 \%$ was female; $65.4 \%$ was married; and $12 \%, 40 \%$, $43 \%$ and $5 \%$ reported a total annual family income of $\$ 10,000$ to $\$ 25,000, \$ 25,000$ to $\$ 50,000, \$ 50,000$ to $\$ 100,000$, and more than $\$ 100,000$, respectively. $H$ alf of thisgroup was randomly assigned to the first study and half to the second.

As subjects in both studies entered the experimental area, they were directed randomly to one of seven different displays of freshly cut flowers, each display comprising three or more separate arrangements ( T able $1)$, all in excellent condition and arranged against a neutral background in white bud bases with no fillers. The 164 subjects in the first study were asked to complete the semantic differential scales; 149 subjects in the second study were given the message-preference questionnaire.

The semantic differential scales (first study) consisted of 25 pairs of contrasting adjectives (and occasional nouns) prepared by the experimenters according to $\mathrm{N}$ unnally (1967). The scales represented a wide range of qualities that could be associated reasonably with flowers. Subjects were instructed to choose the arrangement they liked most and then to ratethat arrangement on the 25 scales (T able 2). The scale ratings could range from -3.5 through 0 to 3.5 , which, for analysis, we transformed to positive numbers by adding 4.5 to each. We asked subjects to rate their preferred arrangement, rather than all arrangements, to make it easier for them to form a reliableopinion and completethetask.

The preference questionnaire (second study) asked subjects which arrangements in the display they would choose to convey each of the eight messages (Table 3 ) to someone close to them. In a fashion similar to the semantic differential scales, we asked subjects to think of and rate a particular person- a sibling, parent, close associate- to make it easier to form a reliable opinion and more interesting to complete the task. Sample size did not permit separate analysis by relationship.

\section{Analysis and results}

Study 1: Semantic differential scales. Themost interesting display preferencesconcerned red roses and petunias. Among displays, the one showing arrangements of three red flowers showed the greatest departure from equal preference, with three red roses overwhelmingly preferred in its set. Petunias, 
however, which are rarely used as commercial cut flowers, were most liked in two of the three displays in which they appeared, but least liked in the third. A bouquet of white petunias was preferred over bouquets of white roses, white daisies, or white carnations. Blue petunias were the favorite choice in a display with blue carnations and blue daisies. H owever, red petunias were the least-liked arrangement when compared with red roses and red carnations.

The central thrust of the semantic differential analysis, however, was to asso ciate clusters of semantic differential scales with the various floral arrangements. The first step toward this end was to compute an overall analysis of variance (AN OVA) to ensure that there were significant differences and that the responses were not simply random. That AN O VA wassignificant at $P<0.001$, indicating reliable differences in Table 2 .

The second step was to use tests to compare means within rows (adjective pairs). Thesetestsweresignificant at $P<0.05$ for the highest vs. lowest means in all pairs except Exciting ... Pacifying, which was borderline significant $(P<0.10)$.

The third step was to tabulate which high and low means applied to specific arrangements in Table 2. The lowest means (I) indicate meanings connected with the adjectives on the left end of the scales and the highest means $(h)$ with those on the right end. To sharpen the discrimination between the left and right ends of the semantic differential scales further, we attended only to those low means that were 3.5 or lower and to those high means that were 5.5 or higher. Thus, the adjectives we took as particularly descriptive of the given arrangements were thosethat significantly differentiated between the highest- and lowest-rated arrangements and fell outside the part of the scales we considered neutral (3.5 to 5.5).

Three red roses had lowest nonneutral means on the adjectives enjoyable, beautiful, expensive, and serious, and highest nonneutral means on the adjectives fancy, sincere, and generous. Accordingly, these seven adjectives are particularly descriptive of, or associated with, three red roses. Similarly, three white petuniaswere especially associated with the left-end adjectives (or nouns) enjoyable, sensitive, beautiful, love, secure, pure, relaxed, and royalty, and the right-end adjectives (or nouns) pacifying, hope, traditional, and happy. Three blue petunias were associated with the adjectives secure and sad (i.e., less happy). Three yellow carnations were associated with the adjectives planful (i.e., not impulsive), lighthearted, hot, strong, and exciting. Six red roses were associated only with the adjective feminine. O ne red carna-
T able 1. Description of seven different floral di splays, the arrangements located in each, and the number of participants in Study 1 choosing that arrangement as most-preferred in that di splay. For each di splay theme, the most-liked arrangement is shown in italics

\begin{tabular}{|c|c|c|}
\hline Display theme & Arrangements within display (code) & $\begin{array}{l}\text { Participant } \\
\text { preference }\end{array}$ \\
\hline \multirow[t]{3}{*}{ Red flowers } & Threered roses ( $3 r R$ ) & 17 \\
\hline & Three red petunias ( $3 \mathrm{rP}$ ) & 1 \\
\hline & Three red carnations ( $3 \mathrm{rC}$ ) & 2 \\
\hline \multirow[t]{4}{*}{ White flowers } & Three white roses (3wR) & 1 \\
\hline & Three white petunias( 3wP) & 9 \\
\hline & O ne white daisy spray (1wD) & 3 \\
\hline & Three white carnations ( $3 w C$ ) & 4 \\
\hline \multirow[t]{3}{*}{ Blue flowers } & Three blue petunias (3bP) & 11 \\
\hline & O ne blue daisy spray (1bD) & 4 \\
\hline & Three blue carnations ( $3 b c$ ) & 5 \\
\hline \multirow[t]{3}{*}{ Yellow flowers } & Three yellow roses (3yR) & 6 \\
\hline & O ne yellow daisy spray (1yD) & 3 \\
\hline & Three yellow carnations ( $3 y c$ ) & 11 \\
\hline \multirow[t]{6}{*}{ Roses } & O ne red rose ( $1 r R$ ) & 0 \\
\hline & O ne white rose ( $1 w R$ ) & 7 \\
\hline & O ne yellow rose (1yR) & 0 \\
\hline & Six red roses $(6 r R)$ & 10 \\
\hline & Six white roses (6wR) & 1 \\
\hline & Six yellow roses (6yR) & 0 \\
\hline \multirow[t]{4}{*}{ Carnations } & Onered carnation ( 1 rC) & 11 \\
\hline & O ne white carnation ( $1 w C$ ) & 3 \\
\hline & Six red carnations (6rC) & 4 \\
\hline & Six white carnations ( $6 w C)$ & 0 \\
\hline \multirow[t]{4}{*}{ Daisies } & O ne white daisy spray (1wD) & 2 \\
\hline & O ne yellow daisy spray (1yD) & 0 \\
\hline & Three white daisy sprays ( $3 w D$ ) & 11 \\
\hline & Three yellow daisy sprays (3yD) & 8 \\
\hline
\end{tabular}

tion was associated with the adjectivesshowy, flexible, and exciting. Finally, three white daisy sprays were associated with the adjectives common and inexpensive.

Abstracting from these various quality clusters, we used the following terms to summarize what seemsto betheunderlying meaning or theme conveyed by most of the adjectives and nouns associated with each cluster. Although standard procedure in social science research, this abstracting is highly subjective, and the resulting summary themes should beviewed principally as a convenience or as postulationsfor further study ( G uilford, 1954). For three red roses, the underlying theme seems to be "dramatic" (that is, fancy, expensive, serious, generous); for threewhite petunias "gentle" (sensitive, pure, relaxed, pacifying, happy); for three blue petunias "reserved" (secure, sad); for three yellow carnations "forceful" (hot, strong, exciting); for one red carnation "sprightly" (showy, exciting); and for three white daisy sprays "simple" (common, inexpensive). Six red roses had only one asso ciated adjective (feminine) and wastherefore not abstracted. Thus, the various arrangements in our first study carry different connotative meanings, described by the different combinations of ad- 
Table 2. Semantic differential word pairsand mean ratingsfor the most-liked arrangement in each floral di splay in Study 1 . On a scale of 1 to 8 , 1 indicates full agrœment wi th the left-mosterm, and 8 indicates full agrement wi th the right-most term.

\begin{tabular}{|c|c|c|c|c|c|c|c|}
\hline \multirow[b]{2}{*}{ Word pairs } & \multicolumn{7}{|c|}{ Arrangement code ${ }^{z}$} \\
\hline & $3 r R$ & $3 w P$ & $3 \mathrm{bP}$ & $3 \mathrm{yC}$ & $6 \mathrm{rR}$ & $1 \mathrm{rC}$ & 3wD \\
\hline Enjoyable...Painful & $2.0 \mathrm{ly}^{\mathrm{y}}$ & 2.01 & 2.5 & 2.5 & 2.4 & 3.0 & 2.4 \\
\hline Sensitive...I nsensitive & 2.4 & $1.7 \mid$ & 3.0 & 3.0 & 2.6 & 2.7 & 3.2 \\
\hline Beautiful...U gly & 2.01 & 2.01 & 2.6 & 3.7 & 2.5 & 2.5 & 3.5 \\
\hline Love...Power & 2.0 & 1.11 & 4.4 & 3.4 & 2.2 & 3.2 & 3.0 \\
\hline Secure...Frightened & 2.8 & 2.51 & 2.51 & 2.7 & 2.8 & 2.7 & 3.7 \\
\hline Pure...I mpure & 2.3 & 2.01 & 3.0 & 3.0 & 3.0 & 3.1 & 3.8 \\
\hline Feminine...M asculine & 3.0 & 2.6 & 2.6 & 3.7 & 2.31 & 3.0 & 3.1 \\
\hline Relaxed...Tense & 3.1 & 2.21 & 3.5 & 2.5 & 3.2 & 3.7 & 3.0 \\
\hline Showy...Subdued & 3.4 & 4.8 & 2.8 & 3.5 & 2.8 & 2.51 & 4.2 \\
\hline Flexible...Rigid & 4.1 & 3.5 & 4.0 & 3.5 & 3.2 & 2.71 & 3.2 \\
\hline Royalty...Commonness & 2.7 & 2.31 & 4.0 & 4.7 & 2.8 & 3.4 & $5.5 \mathrm{~h}$ \\
\hline Expensive...I nexpensive & $1.8 \mid$ & 2.0 & 4.5 & 4.9 & 3.3 & 4.5 & $6.0 \mathrm{~h}$ \\
\hline Exciting...Pacifying & 4.2 & $5.5 \mathrm{~h}$ & 3.3 & 3.8 & 3.6 & 3.2 & 5.0 \\
\hline Planful...I mpulsive & 4.7 & 5.1 & 4.1 & 3.21 & 3.6 & 5.2 & 4.7 \\
\hline Serious...Lighthearted & 2.81 & 3.8 & 5.0 & $6.3 \mathrm{~h}$ & 3.8 & 4.1 & 6.0 \\
\hline Cold...H ot & 5.7 & 4.8 & 4.6 & $6.5 \mathrm{~h}$ & 5.5 & 5.0 & 5.2 \\
\hline Weak...Strong & 5.7 & 4.8 & 4.5 & $6.4 \mathrm{~h}$ & 6.0 & 6.1 & 5.1 \\
\hline Plain...Fancy & $7.1 \mathrm{~h}$ & 6.0 & 5.5 & 6.3 & 5.5 & 5.5 & 4.0 \\
\hline Insincere...Sincere & $6.6 \mathrm{~h}$ & 5.2 & 5.4 & 6.4 & 6.0 & 6.1 & 5.1 \\
\hline D espair...H ope & 7.0 & $7.4 \mathrm{~h}$ & 5.0 & 6.5 & 5.3 & 5.0 & 5.3 \\
\hline Boring...Exciting & 6.9 & 6.5 & 5.7 & $7.0 \mathrm{~h}$ & 5.7 & 5.7 & 5.0 \\
\hline Stingy...Generous & $7.2 \mathrm{~h}$ & 6.8 & 5.6 & 6.5 & 6.5 & 5.0 & 6.4 \\
\hline N ovel...T raditional & 7.2 & $7.4 \mathrm{~h}$ & 5.5 & 6.7 & 6.1 & 5.1 & 6.7 \\
\hline Sad...H appy & 6.6 & $7.3 \mathrm{~h}$ & 5.7 & 7.0 & 6.5 & 5.7 & 6.5 \\
\hline
\end{tabular}

23rR =threred roses, 3wP =three white petunias, 3bP =threeblue petunias, 3yC =threyellow carnations, 6rR =six red roses, $1 \mathrm{rC}=$ onered carnation; 3wD $=$ three white daisy sprays.

yM eansused toaccumulatewordsdescribing each arrangement. I =lowest mean $\leq 3.5$, indicating thel eft-most word; $h=h i g h e s t$ mean $\geq 5.5$, indicating therightmost word.

jectives and nouns that the subjects associated with them and summarized in different abstracted themes.

Study 2: M essage-preference questionnaire Table 3 contains the frequencies with which the subjects in the second study endorsed a particular three-flowered arrangement as their favorite for conveying a given message. As in the first study, we used $\chi^{2}$ as a preliminary test for significant differences in the overall table. This test was significant at $P$ $<0.001$. Then we used KolomogorovSmirnoff one-sample tests to test for significant differences within rows (across messages). The messages "I love you" and "Congratulations" weresignificant at $P<0.05$, and "I apologize" was borderline significant ( $P<$ $0.10)$, indicating that different arrangements were associated with these three messages. No other Kolomogorov-Smirnoff tests reached the 0.10 level. The KolomogorovSmirnoff test is very conservative, especially for discontinuous variables such as these, so we are quite confident that these differences are real (Siegel, 1956).

Visual inspection of Table 3 indicated that the differences for "I love you" and "I apologize" apparently came from the high endorsements for three red roses, especially relative to three yellow carnations and three whitedaisy sprays, and the differencefor " C ongratulations" came from three red roses and three bluepetunias, especially relativeto three yellow carnations. Thus, we conclude that three red roses are particularly appropriate for conveying the messages "I love you" and "I apologize" and three yellow carnations and three white daisy sprays are particularly inappropriate, and three red roses and three blue petunias are especially appropriate for conveying "Congratulations" and three yellow carnations are particularly inappropriate.

Referring to the abstracted thematic meaningsconnected with these arrangements, "I love you" and "I apologize" are associated with "dramatic" but not "forceful" or "simple" meanings, "C ongratulations" with either "dramatic" or "reserved" but not "forceful" meanings. These differences may be functions of interactions between different kinds of message senders and message receivers.

\section{Discussion}

These pilot studies of the connections between language and flowers identified six differentiating clusters of adjectivesand nouns based on subjective ratings supplied by a 
rather broad, but indeterminate, sample of adults in M innesota. These studies occasion some interesting insightsinto thelanguage of flowers, but they also have some important shortcomings that only further research can remedy.

Asto insights, perhapsthemost interesting is that the 25 adjectives (and nouns) can be associated reliably with six clusters of meaning, which in turn can be sorted readily into four categories of personality or personal temperament that date back to $\mathrm{H}$ ippocrates' four humors: "dramatic" and "sprightly" seem commensuratewith $\mathrm{H}$ ippocrates' "sanguine" (optimistic, enthusiastic); "reserved" with "phlegmatic" (hard to arouse); "simple" and "gentle" with "melancholic" (quiet and pensive); and "forceful" with "choleric" (demanding and acerbic). D oyle (1992) traced the history and definition of these four temperaments from $\mathrm{H}$ ippocrates and other ancientsto such modern authorsasJ ung (1971), M aslow (1964), Fromm (1976), M errill and Reid (1981), D oyle (1991), T ellegen (1985), and others(Table 4), and proposed that these four categories may define the fundamental dimensions of personality. If so, it is not surprising that they also may comprise the fundamental dimensions of florigraphy.

Similarly, our categories can be associated with common interpersonal messages in ways that seem sensible and consistent with existing theory. I n particular, "I loveyou," "I apologize," and "Congratulations" agreewith the drama of three red roses.
As to deficiencies that require further research, our two studies do not distinguish between the effects of species and of color. Birren (1972, 1940, 1988), in his extensive studies of color independent of flowers, associated long-wavelength colors (red, orange) with extroverted personalitiesand short-wavelength colors (blue, violet) with introverted personalities. Even more specifically, he associated red with vitality, blue with avoidance, yellow with reformer or activist personalities, and green with social or affable personalities. Further experimental manipulation will be necessary to distinguish the language of the floral species from the language of the color.

Wealso did not manipulatefloral massin our studies. Does a single rose or petunia blossom carry different meaning than a full arrangement? These pilot studies did not explore the possibly intricate interactions between flower characteristics such as species, color, and mass, and human characteristics such as explicit personality types of the message sender and message receiver or the nature of the relationships between these peo ple (degrees of closeness; social roles such as parent, employee, or neighbor; age and social class; ethnic background). These factors, too, ultimately will haveto beaddressed.

$\mathrm{N}$ evertheless, these results should be useful in targeting audiences in advertising and marketing, especially of floral items, and in applied communications research. Our work also provides encouraging signs that further study of the language of flowers may

Table 3. Mesagesand mesage endorsement frequenciesin Study 2 for the most-liked arrangementsfrom fi ve of the floral di splaysin Study 1.

\begin{tabular}{lccccc}
\hline & \multicolumn{3}{c}{ Arrangement code } & \\
\cline { 2 - 5 } M essage & 3rR & 3wP & 3bP & 3yC & 3wD \\
\hline I'm Thinking of You & 23 & 19 & 23 & 22 & 22 \\
Get Well Soon & 27 & 15 & 19 & 21 & 28 \\
I M iss You & 31 & 23 & 21 & 22 & NS \\
I Like You & 34 & 19 & 28 & 23 & NS \\
Thank You & 40 & 17 & 27 & 27 & NS \\
I Apologize & 44 & 25 & 29 & 22 & NS \\
Congratulations & 50 & 27 & 50 & 23 & 22 \\
I Love You & 55 & 37 & 31 & 16 & 27 \\
\hline
\end{tabular}

23rR =three red roses, $3 \mathrm{wP}=$ three white petunias, $3 \mathrm{bP}=$ three blue petunias, $3 \mathrm{yC}=$ thre yellow carnations, $3 \mathrm{wD}=$ three white daisy sprays. ${ }_{\mathrm{Ns}, * * * *} \mathrm{~N}$ onsignificant or significant at $\mathrm{P} \leq 0.1$ or 0.05 , respectively.

Table 4. A lignment of personality-personal temperament categories with the proposed floral themes

\begin{tabular}{|c|c|c|c|c|}
\hline Authority & Simple & Forceful & D ramatic & Reserved \\
\hline H ippocrates & M elancholic & Choleric & Sanguine & Phlegmatic \\
\hline M aslow & Belonging & Strength & Reputation & Safety \\
\hline M errill \& Reid & Amiable & D river & Expressive & Analytical \\
\hline D oyle & Affiliation & Achievement & Expression & Security \\
\hline
\end{tabular}


build interesting and useful bridges between the personality and the natural sciences through the critical study of people-plant interactions.

\section{Literature C ited}

A nonymous 1991. The language of flowers. Family Circle 104(6):72-79.

A nonymous 1968. Thelanguage of flowers. M ichael Joseph, England.

Birren, F. 1940. C haracter analysis through color. Crimson, Westport, Conn.

Birren, F. 1972. Color psychology and color therapy. U niv. Press, N ew H yde Park, N.Y.

Birren, F. 1988. The symbolism of color. Citadel, Secaucus, N.J .

Doyle, K.O. 1991. Construction of the money orientation measure (MOM). Lure, lore, and liquidity: The $\mathrm{H}$ ofstra conference on the meaning of money. H ofstra U niv., H empstead, N.Y.

D oyle, K . O 1992. T oward a psychology of money. Amer. Behavioral Sci. 35(6):708-724.

Fromm, E. 1976. To haveor to be?H arper \& Row, N ew York.

Guilford, J.P. 1954. Psychometric methods. M CG raw-H ill, N ew York.
J ung, C.G. 1971. The portableJ ung. Viking, N ew York.

K eenan, N . 1990. Florigraphy, or the language of flowers. Flower \& G arden 34(3):36-37.

Marsh, J. and K. Greenaway. 1978. The illuminated language of flowers. M acdonald and J ane's, London.

Maslow, A.H . 1954. M otivation and personality. $\mathrm{H}$ arper \& Row, N ew York.

M errill, D . and R . R eid. 1981. Personal styles and effective performance. Chilton, Radnor, $\mathrm{Pa}$.

N unnally, J.C. 1967. Psychometric theory. M cGraw-H ill, N ew York.

Osgoode, C.E. 1952. The nature and measurement of meaning. Psychol. Bul. 49:197-237.

Pickles, S. 1990. The language of flowers. $\mathrm{H}$ armony Books, N ew York.

Profess onal Plant G rowersA ssn. 1991. G allup survey givesinsight into gift-giving preferences. PPGA $\mathrm{N}$ ews (M arch).

Si egel, S. 1956. N onparametric statistics. M cG raw$\mathrm{H}$ ill, N ew York.

Tellegen, A . 1985. Structures of mood and personality and their relevanceto assessing anxiety, with an emphasis on self-rapport. In A.H. Tuma and J.D. Moser (eds.). Anxiety and the anxiety disorder. Lawrence Earlbaum, H illsdale, N.J. 